\title{
Effect of supplementing pasteurized milk balancer products to heat-treated whole milk on the growth and health of dairy calves
}

\author{
K. M. Glosson, ${ }^{* 1}$ B. A. Hopkins, ${ }^{*}$ S. P. Washburn, ${ }^{*}$ S. Davidson, ${ }^{*}$ G. Smith, ${ }^{*}$ T. Earleywine, $†$ and C. Mał \\ *Department of Animal Science, North Carolina State University, Raleigh 27695 \\ †Land O'Lakes Animal Milk Products, St. Paul, MN 55118 \\ fDepartment of Statistics, North Carolina State University, Raleigh 27695
}

\section{ABSTRACT}

Two experiments were conducted to determine the growth and health effects of supplementing heat-treated whole milk with pasteurized milk balancer products in calf-feeding programs. All calves were removed from their dams at birth (d 0), fed $3.8 \mathrm{~L}$ of heat-treated colostrum, and received assigned treatments from $\mathrm{d} 1$ until weaning at $\mathrm{d} 56$. Calves were weighed and skeletal measurements taken every $7 \mathrm{~d}$ from d 0 until 56. Average daily gain $(\mathrm{ADG})$ and feed efficiency $(\mathrm{FE})$ were calculated. In experiment 1, 80 Holstein heifer calves were used to investigate the effects of supplementing 2 levels of heat-treated whole milk with or without a pasteurized all-milk balancer. Four dietary treatments $(\mathrm{n}=20)$ were used. Calves receiving milk $(\mathrm{M})$ and milk plus balancer $(\mathrm{M}+\mathrm{B})$ were fed $3.8 \mathrm{~L}$ of milk divided into 2 equal feedings daily. Calves fed increased milk (IM) and increased milk plus balancer (IM+B) received $3.8 \mathrm{~L}$ of milk divided into 2 equal feedings from $\mathrm{d} 1$ to $14,5.7 \mathrm{~L}$ from d 15 to 42 , and $2.85 \mathrm{~L}$ fed once daily from $\mathrm{d} 43$ to 56 . Treatments $\mathrm{M}+\mathrm{B}$ and $\mathrm{IM}+\mathrm{B}$ included pasteurized all-milk balancer fed at a rate of $0.23 \mathrm{~kg}$ per $3.8 \mathrm{~L}$ of milk. In experiment 2, 72 Holstein heifer calves were used to investigate the effects of supplementing either a pasteurized all-milk balancer or a pasteurized protein-blend milk balancer. Three dietary treatments $(\mathrm{n}=24)$ were used. Calves were fed $3.8 \mathrm{~L}$ of milk divided into 2 equal feedings from d 1 to 14 and $5.7 \mathrm{~L}$ from d 15 to 56 . Treatment IM did not include any supplements. Balancer was added to $\mathrm{IM}+\mathrm{B}$ and increased milk plus protein-blend balancer $(\mathrm{IM}+\mathrm{PB})$. Balancer was supplemented at a rate of $0.23 \mathrm{~kg}$ per $3.8 \mathrm{~L}$ of milk. In experiment 1 , calves fed $\mathrm{IM}+\mathrm{B}$ had greater average body weight (BW) and average daily gain compared with calves given other treatments. Calves fed 5.7 L of milk had greater FE than those fed $3.8 \mathrm{~L}$ regardless of balancer added. In experiment 2 ,

Received July 3, 2014.

Accepted October 25, 2014.

${ }^{1}$ Corresponding author: kmglosso@gmail.com calves fed $\mathrm{IM}+\mathrm{B}$ and $\mathrm{IM}+\mathrm{PB}$ had greater $\mathrm{BW}$ when compared with calves given M. Calves fed $\mathrm{IM}+\mathrm{PB}$ had comparable $\mathrm{BW}$ and $\mathrm{FE}$ to calves given $\mathrm{IM}+\mathrm{B}$. The enhanced calf-feeding programs evaluated in this study were successful in increasing growth in preweaned calves when supplementing milk balancer product to heat-treated whole milk. Health scores of fecal, respiratory, and attitude determined illness. Feces were looser for calves receiving $\mathrm{IM}+\mathrm{B}$ and $\mathrm{IM}+\mathrm{PB}$, but attitude scores did not confirm an illness and so overall health was not different between treatments.

Key words: dairy calf, milk balancer

\section{INTRODUCTION}

Enhanced calf feeding is not a new concept, but many different techniques exist for producers to use to optimize the growth and health of preweaned dairy calves. Early management of preweaned calves, including nutrition, feeding frequencies, and weaning ages, may also have long-term effects on their subsequent performance as milking cows (Kehoe et al., 2007; Drackley, 2008; Soberon et al., 2012). Those long-term effects are thought to be linked to the effect of preweaning nutrition on allometric mammary growth (Brown et al., 2005; Daniels et al., 2006). However, increased nutrition after weaning does not have the same effect on allometric mammary growth (Brown et al., 2005; Meyer et al., 2006). Whereas many management approaches are available for rearing calves, the goal of producing a healthy, productive replacement heifer remains the same. Calf-feeding programs can use whole milk or milk replacers that include unique advantages and disadvantages. On-farm whole milk can be used as a low-cost option for providing high-quality nutrients, but nutrient content can fluctuate greatly and is limited to what the herd produces. On-farm batch pasteurizers can also be used to decrease the bacterial load and to destroy any high-risk disease organisms associated with feeding raw fluid milk, shown as effective by previous studies (Godden et al., 2006; Elizondo-Salazar et al., 2010). Conversely, milk replacers are an out-of-pocket 
expense but can provide a more concentrated, consistent source of nutrients depending on the product. Use of milk balancer products combined with whole milk has the potential to increase the DM of whole milk without increasing the volume of whole milk offered, allowing producers to extend the supply of whole milk available for preweaning calf management.

Milk replacers and milk balancers can also contain alternative protein products to further reduce expenses by substituting milk proteins with a mixture of plant proteins and other animal proteins. Those alternative protein sources can reduce feeding costs, but could decrease digestibility and increase digesta movement through the gastrointestinal tract resulting in decreased growth rates (Montagne et al., 1999; Drackley, 2008). Alternative animal proteins, such as plasma protein, have been shown to be more effectively digested by the calf, but are not as appealing as the lower-cost plant proteins (Morrill et al., 1995; Quigley and Wolf, 2003).

The objective of experiment 1 was to determine the effects of supplementing 2 levels of heat-treated whole milk with or without an added balancer product on the growth and health of dairy calves. The objective of experiment 2 was to determine the effect of feeding $5.7 \mathrm{~L}$ of heat-treated whole milk, supplemented with or without an all-milk pasteurized milk balancer or a protein-blend pasteurized milk balancer on the growth and health of dairy calves.

\section{MATERIALS AND METHODS}

\section{Animals and Treatment Assignments (Experiment 1)}

Holstein heifer calves $(\mathrm{n}=80)$ including 40 calves from the North Carolina Department of Agriculture Piedmont Research Station (PRS) and 40 calves from the North Carolina State University Lake Wheeler Road Dairy Educational Unit (LWD), were randomly assigned to 4 treatment groups. Twenty heifer calves were assigned at birth to each of the 4 treatments with 10 calves at each location. Calves were blocked by date of birth and location so that all treatments were represented in every 4 calves born at 1 location. No Holstein heifer calves were excluded from the trial.

In treatment 1 , milk only (M), calves were fed 3.8 $\mathrm{L}$ of heat-treated whole milk divided into 2 equal feedings daily until weaning at $56 \mathrm{~d}$ of age. This treatment supplied the calf with an approximate milk DM of 0.45 $\mathrm{kg} / \mathrm{d}$, consisting of only whole milk ( $12.5 \% \mathrm{DM}, 25.6 \%$ $\mathrm{CP}$, and $28 \%$ fat).

In treatment 2 , milk plus balancer $(\mathbf{M}+\mathbf{B})$, calves were fed $3.8 \mathrm{~L}$ of heat-treated whole milk with 0.23 $\mathrm{kg}$ of an all-milk balancer added per $3.8 \mathrm{~L}$. This was divided into 2 equal feedings daily, $0.115 \mathrm{~kg}$ of milk balancer per feeding, until weaning at $56 \mathrm{~d}$ of age. This treatment supplied the calf with an approximate milk DM of $0.68 \mathrm{~kg} / \mathrm{d}$, consisting of whole milk and pasteurized milk balancer $(17.6 \% \mathrm{DM}, 35.8 \% \mathrm{CP}$, and $31.0 \%$ fat).

In treatment 3 , increased milk (IM), calves were fed $3.8 \mathrm{~L}$ of heat-treated whole milk divided into 2 equal feedings daily for the first $14 \mathrm{~d}$ after birth, then fed $5.7 \mathrm{~L}$ of heat-treated whole milk divided into 2 equal feedings daily for $35 \mathrm{~d}$ (until $49 \mathrm{~d}$ of age), and then fed $2.85 \mathrm{~L}$ once daily in the morning feedings for $7 \mathrm{~d}$ until weaning at $56 \mathrm{~d}$ of age. This treatment supplied the calf with an approximate milk DM of $0.45 \mathrm{~kg} / \mathrm{d}$, consisting of only whole milk (12.5\% DM, $25.6 \% \mathrm{CP}$, and $28 \%$ fat), from 1 to $14 \mathrm{~d}$ of age, $0.68 \mathrm{~kg}$ of milk DM/d from 15 to $49 \mathrm{~d}$ of age, and $0.34 \mathrm{~kg}$ of milk $\mathrm{DM} / \mathrm{d}$ from 50 to $56 \mathrm{~d}$ of age.

In treatment 4 , increased milk plus balancer $(\mathbf{I M}+\mathbf{B})$, calves were fed $3.8 \mathrm{~L}$ of heat-treated whole milk, with $0.23 \mathrm{~kg}$ of an all-milk balancer added per $3.8 \mathrm{~L}$ or 0.115 $\mathrm{kg} /$ feeding, divided into 2 equal feedings for the first 14 $\mathrm{d}$ after birth. Calves were then fed $5.7 \mathrm{~L}$ of heat-treated whole milk divided into 2 equal feedings daily for 35 $\mathrm{d}$ (until $49 \mathrm{~d}$ of age), with $0.23 \mathrm{~kg}$ of supplemented all-milk balancer per $3.8 \mathrm{~L}$ or $0.172 \mathrm{~kg}$ per feeding, and then fed $2.85 \mathrm{~L}$ once daily in the morning feeding for $7 \mathrm{~d}$ until weaning at $56 \mathrm{~d}$ of age, with $0.23 \mathrm{~kg}$ of supplemented all-milk balancer per $3.8 \mathrm{~L}$ or $0.172 \mathrm{~kg} / \mathrm{d}$. This treatment supplied the calf with an approximate milk DM of $0.68 \mathrm{~kg} / \mathrm{d}$, consisting of whole milk and pasteurized milk balancer $(17.6 \% \mathrm{DM}, 35.8 \% \mathrm{CP}$, and $31.0 \%$ fat), from 1 to $14 \mathrm{~d}$ of age; $1.02 \mathrm{~kg}$ of milk DM/d from 15 to $49 \mathrm{~d}$ of age; and $0.51 \mathrm{~kg}$ of milk DM/d from 50 to $56 \mathrm{~d}$ of age.

\section{Animals and Treatment Assignments (Experiment 2)}

Holstein heifer calves $(\mathrm{n}=72)$, including 36 calves from PRS and 36 calves from LWD, were randomly assigned to 3 treatment groups. Twenty-four heifer calves were assigned at birth to each of the 3 treatments, with 12 calves at each location. Calves were blocked by date of birth and location so that all treatments were represented in every 3 calves born at 1 location. No Holstein heifer calves were excluded from the trial.

In treatment 1 , IM, calves were fed $3.8 \mathrm{~L}$ of heattreated whole milk divided into 2 equal feedings daily for the first $14 \mathrm{~d}$ after birth, then fed $5.7 \mathrm{~L}$ of heattreated whole milk divided into 2 equal feedings daily for $35 \mathrm{~d}$ (until $49 \mathrm{~d}$ of age), and then fed $2.85 \mathrm{~L}$ once daily in the morning feedings for $7 \mathrm{~d}$ until weaning at $56 \mathrm{~d}$ of age. This treatment supplied the calf with an approximate milk DM of $0.45 \mathrm{~kg} / \mathrm{d}$, consisting of only whole milk (12.5\% DM, $25.6 \% \mathrm{CP}$, and $28 \%$ fat), from 
1 to $14 \mathrm{~d}$ of age, $0.68 \mathrm{~kg}$ of milk DM/d from 15 to 49 $\mathrm{d}$ of age, and $0.34 \mathrm{~kg}$ of milk DM/d from 50 to $56 \mathrm{~d}$ of age.

In treatment $2, \mathrm{IM}+\mathrm{B}$, calves were fed $3.8 \mathrm{~L}$ of heattreated whole milk, with $0.23 \mathrm{~kg}$ of an all-milk balancer added per $3.8 \mathrm{~L}$ or $0.115 \mathrm{~kg} /$ feeding, divided into 2 equal feedings for the first $14 \mathrm{~d}$ after birth and then fed $5.7 \mathrm{~L}$ of heat-treated whole milk divided into 2 equal feedings daily for $42 \mathrm{~d}$ (until weaning at $56 \mathrm{~d}$ of age), with $0.23 \mathrm{~kg}$ of supplemented all-milk balancer per 3.8 $\mathrm{L}$ or $0.17 \mathrm{~kg} /$ feeding. This treatment supplied the calf with an approximate milk DM of $0.68 \mathrm{~kg} / \mathrm{d}$, consisting of whole milk and pasteurized milk balancer (17.6\% DM, $35.8 \% \mathrm{CP}$, and $31.0 \%$ fat), from 1 to $14 \mathrm{~d}$ of age and $1.02 \mathrm{~kg}$ of milk DM/d from d 15 until weaning at $56 \mathrm{~d}$ of age.

In treatment 3 , increased milk plus a protein-blend milk balancer $(\mathbf{I M}+\mathbf{P B})$, calves were fed $3.8 \mathrm{~L}$ of heattreated whole milk, with $0.23 \mathrm{~kg}$ of a protein-blend milk balancer added per $3.8 \mathrm{~L}$ or $0.115 \mathrm{~kg} /$ feeding, divided into 2 equal feedings for the first $14 \mathrm{~d}$ after birth and then fed $5.7 \mathrm{~L}$ of heat-treated whole milk divided into 2 equal feedings daily for $42 \mathrm{~d}$ (until weaning at $56 \mathrm{~d}$ of age), with $0.23 \mathrm{~kg}$ of supplemented protein-blend milk balancer per $3.8 \mathrm{~L}$ or $0.172 \mathrm{~kg} /$ feeding. This treatment supplied the calf with an approximate milk DM of 0.68 $\mathrm{kg} / \mathrm{d}$, consisting of whole milk and pasteurized milk balancer $(17.6 \% \mathrm{DM}, 35.8 \% \mathrm{CP}$, and $31.0 \%$ fat), from 1 to $14 \mathrm{~d}$ of age and $1.02 \mathrm{~kg}$ of milk DM/d from d 15 until weaning at $56 \mathrm{~d}$ of age.

\section{Milk Balancer Products}

The all-milk balancer (Land O'Lakes All-Milk Pasteurized Milk Balancer Product, St. Paul, MN), at 25\% $\mathrm{CP}$ and $10 \%$ fat, included ingredients of dried whey, dried whey protein concentrate, dried whey product, dried skim milk, dried milk protein, animal fat (preserved with ethoxyquin), lecithin, polysorbate 80 , dicalcium phosphate, calcium carbonate, yeast extract, methionine supplement, L-lysine, calcium pantothenate, biotin, ascorbic acid, pyridoxine hydrochloride, folic acid, choline chloride, roughage products, calcium silicate, zinc methionine complex, manganese methionine complex, copper lysine complex, iron amino acid complex, cobalt sulfate, ethylenediamine dihydroiodide, vitamin $\mathrm{A}$ acetate, vitamin $\mathrm{D}_{3}$ supplement, vitamin $\mathrm{E}$ supplement, thiamine mononitrate, riboflavin, niacin supplement, vitamin $\mathrm{B}_{12}$ supplement, selenium yeast, and natural and artificial flavor.

The alternative protein-blend milk balancer (Land O'Lakes Protein-Blend Pasteurized Milk Balancer Product), also at $25 \% \mathrm{CP}$ and $10 \%$ fat, substituted half of the milk protein with a combination of soy protein and animal plasma. It included identical ingredients to the all-milk version with the exceptions of added soy isolate, protein modified soy flour, and animal plasma.

The osmolality was measured using a freezing point osmometer (Cornell University Animal Health Diagnostic Center, Ithaca, NY). The overall osmolality of the whole milk used during the trial was $280 \mathrm{mOsm} / \mathrm{L}$. The addition of a milk balancer product at a ratio of $0.23 \mathrm{~kg}$ per $3.8 \mathrm{~L}$ of whole milk resulted in an increase to 483 $\mathrm{mOsm} / \mathrm{L}$ for the combined whole milk and balancer.

\section{Nutrition of Neonatal Calves}

All calves were removed from their dams immediately after birth, to prevent nursing of raw colostrum, and moved to individual calf hutches. Calves were then fed $3.8 \mathrm{~L}$ of high-quality heat-treated colostrum, tested in the green zone $\left(>50 \mathrm{~g}\right.$ of $\mathrm{IgG} / \mathrm{L}$ of milk at $\left.22^{\circ} \mathrm{C}\right)$ using a colostrometer, within 1 to $2 \mathrm{~h}$ after birth with no subsequent colostrum feedings. Colostrum was heattreated and stored in Dairy Tech Perfect Udder bags (Windsor, CO) during the trial. Using a model DT30G Dairy Tech commercial batch pasteurizer, colostrum and whole milk fed to the trial calves was heat-treated by heating to $60^{\circ} \mathrm{C}$ for $60 \mathrm{~min}$ and evaluated (Godden, 2008). From d 1, all calves were offered a high-quality calf starter, averaging $88.2 \pm 1.1 \% \mathrm{DM}( \pm \mathrm{SD})$ with a CP level of $21.7 \pm 2.1 \% \mathrm{DM}$, and free-choice water. The calf starter contained $15 \%$ cottonseed hulls, ground corn grain, soybean meal, $48 \%$ protein, soy hulls, dried molasses, salt, monensin, vitamins, and minerals. The North Carolina State VTM pack (Raleigh) included calcium carbonate, manganese, sulfate, zinc sulfate, copper sulfate, ferrous sulfate, sodium selenite, zinc oxide, cobalt sulfate, calcium iodate, vitamin E supplement, vitamin A supplement, and vitamin $\mathrm{D}_{3}$ supplement. In both experiments, the heat-treated whole milk fed to the calves consisted of available nonsaleable milk with the addition of saleable whole milk collected from the bulk tank to meet the amounts needed for the treatment protocols. Table 1 shows the nutrient analysis of the milk balancers.

\section{Sampling and Observation Recording Protocol}

Thirty-milliliter samples of colostrum were taken before and after heat-treating in the Dairy Tech Perfect Udder colostrum pasteurization bags. Samples were immediately frozen and transported on ice. Pre- and postsamples were evaluated by the University of Saskatchewan (Saskatoon, Canada) for IgG concentrations by single radial immunodiffusion assay. This was necessary to verify the heat treatment did not cause excessive denaturation and destruction of $\operatorname{IgG}$ in amounts 
Table 1. All-milk milk balancer and protein-blend milk balancer label nutrient analysis

\begin{tabular}{lcc}
\hline Item & $\begin{array}{c}\text { All-milk } \\
\text { milk balancer }\end{array}$ & $\begin{array}{c}\text { Protein-blend } \\
\text { milk balancer }\end{array}$ \\
\hline $\mathrm{CP}^{1}(\%)$ & 25.0 & 25.0 \\
Crude fat $^{1}(\%)$ & 10.0 & 10.0 \\
Crude fiber $^{1}(\%)$ & 0.25 & 0.15 \\
Calcium $^{1}(\%)$ & 0.70 & 0.70 \\
Calcium $^{2}(\%)$ & 1.25 & 1.25 \\
Sodium $^{2}(\%)$ & 1.50 & 1.50 \\
Phosphorus $^{1}(\%)$ & 0.70 & 0.70 \\
Vitamin $^{1}(\mathrm{IU} / \mathrm{kg})$ & 66,371 & 66,371 \\
Vitamin $\mathrm{D}^{1}(\mathrm{IU} / \mathrm{kg})$ & 16,592 & 16,592 \\
Vitamin $\mathrm{E}^{1}(\mathrm{IU} / \mathrm{kg})$ & 331 & 331 \\
\hline
\end{tabular}

${ }^{1}$ Not less than.

${ }^{2}$ Not more than.

that would cause failure of passive transfer. An SPC measurement was performed on the pre- and postheat-treatment milk samples, as well as the colostrum samples by PRS as a verification of heat treatment (Nero et al., 2006). A weekly sample of the whole milk was taken before heat treatment, after heat treatment, and after the last calf was fed, then frozen until later analysis for SPC.

To determine the successful transfer of passive immunity in the calf, a jugular blood sample was taken from each calf between 24 and $48 \mathrm{~h}$ after the colostrum was fed. Samples were immediately centrifuged $\left(\sim 2,500-3,000 \times g\right.$ at $\left.24^{\circ} \mathrm{C}\right)$ and the blood serum supernatant was extracted and frozen. The University of Saskatchewan analyzed the serum samples for the IgG content through a single radial immunodiffusion assay (Cho and Kramer, 1970).

Milk refusals were weighed and measured daily and calf starter samples were taken weekly, composited by month, and analyzed for nutrient contents. The calf starter offered was recorded daily and feed refusals were recorded weekly. Samples of both were also taken weekly. Dry matter intake, ADG, and feed efficiency (FE) were then calculated based on the collected data. Body weight, hip height (HH), hip width (HW), and withers height (WH) of each calf was measured at birth and then every $7 \mathrm{~d}$ through $63 \mathrm{~d}$.

While in the individual hutches, calves were monitored daily and scored for fecal appearance, respiratory health, and calf attitude. Fecal scores were assigned as $1=$ normal, $2=$ soft, $3=$ runny, and $4=$ watery. Respiratory scores were $1=$ normal, $2=$ runny nose, $3=$ heavy breathing, $4=$ moist cough, and $5=$ dry cough. Calf attitude scores were given as $1=$ normal and alert, $2=$ slow to drink milk or appears mildly depressed, 3 $=$ moderately depressed, requiring encouragement to get up and slow to drink, and $4=$ severely depressed and an unwilling to get up or drink milk. Calves were treated with scour boluses and electrolytes when diar- rhea was suspected at a fecal score of 4 or multiple scores of 3 according to the visual guidelines listed in the protocol regardless of illness verification. In cases of diarrhea, PRS and LWD used a combination of oral oxytetracycline tablets and an oral electrolyte solution, composed of dextrose, sodium acetate, potassium chloride, glycine, sodium citrate, and sodium chloride.

Milk samples from LWD were frozen, and then transported to PRS labs for SPC analysis. Samples taken at PRS were frozen before testing to ensure similar treatment was given to all milk samples regardless of location. Calf starter samples of feed offered and refused were composited by month and analyzed by Cumberland Valley Analytical Services (Maugansville, MD) for nutrient content at the end of the trial cycle.

\section{Statistical Design and Data Analyses}

In experiment 1, a randomized complete block design was used where calves were assigned to a treatment at birth. The recorded data were analyzed in SAS (Cary, $\mathrm{NC}$ ) as follows: the ADG values were calculated using PROC REG; ADG, FE, starter DMI, total DMI, and health scores used PROC GLM; and BW, WH, HH, and HW used PROC MIXED for repeated measures. For PROC MIXED, treatment and time were considered fixed, whereas calf and location were considered random variables. $P$-values were evaluated under the Tukey adjustment.

In experiment 2, a randomized complete block design was used where calves were assigned to treatment at birth. The recorded data were analyzed in SAS as follows: the ADG were calculated using PROC REG; ADG and health scores used PROC GLM; weekly FE, starter DMI, and total DMI used PROC MIXED; and BW, WH, HH, and HW used PROC MIXED for repeated measures. For the PROC MIXED, treatment and time were considered fixed, whereas calf and location were considered random variables. A contrast statement was used to compare the unsupplemented treatment, $\mathrm{M}$, versus the average of the supplemented treatments, $\mathrm{M}+\mathrm{B}$ and $\mathrm{M}+\mathrm{PB}$, and between the supplemented treatments, $\mathrm{M}+\mathrm{B}$ and $\mathrm{M}+\mathrm{PB}$.

Average daily gain was calculated by using weekly BW measurements to make a preweaning growth regression curve for each calf. The overall preweaning ADG slopes were then used to determine the differences by treatment in a general linear model. Feed efficiency was calculated using total preweaning gain per unit of total DMI for the overall preweaning period. Total DMI, including milk DM (12.5\% DM) and starter DM, was calculated weekly. Health scores were divided between scores of 0 to 2 and 3 to 5 . The number of days an animal scored 3 to 5 for fecal, respiratory, or attitude 
scores was averaged per calf throughout the preweaning period. The average number of days calculated per calf was then compared between treatments.

Growth data were analyzed, separately, in PROC MIXED for repeated measures over time. Treatment, time, and interactions were fixed effects, with calf and location considered random effects to allow for inference to the population. Analyses were conducted for $\mathrm{BW}, \mathrm{WH}, \mathrm{HH}$, and HW. Statistical significance was determined at $P \leq 0.05$. Other data, such as milk quality samples, SPC and IgG concentration, serum protein, and IgG levels, were summarized and reported as means \pm SD without statistical comparisons.

\section{RESULTS AND DISCUSSION}

\section{Growth Data}

In experiment 1 , average $\mathrm{BW}, \mathrm{HH}, \mathrm{HW}, \mathrm{WH}, \mathrm{ADG}$, starter DMI, and FE are shown in Table 2. All Holstein heifer calves entered the trial at birth and were assigned to a treatment where all treatments were represented in each block of 4 calves born. Calves fed $\mathrm{IM}+\mathrm{B}$ were greater $(P<0.05)$ in average BW $(58.8$ $\mathrm{kg}$ ) than the other groups whereas calves receiving $\mathrm{M}$, $\mathrm{M}+\mathrm{B}$, and IM had similar average BW, as illustrated in Figure 1 and Table 2. The group fed IM had higher ADG compared with $\mathrm{M}$, whereas calves fed $\mathrm{M}+\mathrm{B}$ were intermediate for ADG between $\mathrm{M}$ and IM (Table 2). No differences $(P>0.2)$ in overall $\mathrm{HH}, \mathrm{HW}$, or $\mathrm{WH}$ were noted among treatments (Table 2). This indicates no change in skeletal structure among treatments, thus the greater average $\mathrm{BW}$ in calves fed $\mathrm{IM}+\mathrm{B}$ may be due to accretion of muscle and fat. Postweaning, the addition of fat through high-energy diets has been linked to earlier onset of puberty. However, during the preweaning period, mammary system development can be affected by increasing the energy in the diet and can cause an increase in mammary cell proliferation (Meyer et al., 2006; Davis Rincker et al., 2008). Calves receiving $\mathrm{IM}+\mathrm{B}$ showed an $\mathrm{ADG}$ of $0.84 \mathrm{~kg} / \mathrm{d}$, whereas calves receiving $\mathrm{M}$ averaged only $0.64 \mathrm{~kg} / \mathrm{d}$, leading to a difference of $11.6 \mathrm{~kg}$ in BW at weaning (Figure 1). In Figure 1, it should also be noted that the weekly $\mathrm{BW}$ of calves receiving $\mathrm{IM}+\mathrm{B}$ became greater $(P \leq$ $0.05)$, compared with calves receiving $\mathrm{M}$ and IM at wk 2 , and became greater $(P \leq 0.05)$ than calves receiving $\mathrm{M}+\mathrm{B}$ at wk 5 . It was also interesting to note that whereas calves fed $\mathrm{M}$ consumed more calf starter, 31.6 $\mathrm{kg}(P<0.02)$, than the other treatments, the calves receiving $0.68(\mathrm{M}+\mathrm{B})$ and $1.02 \mathrm{~kg}(\mathrm{IM})$ of milk $\mathrm{DM}$ for the majority of the preweaning period consumed similar amounts of calf starter regardless of the $45 \%$ increase of milk DM from $\mathrm{M}+\mathrm{B}$ and $\mathrm{IM}$ to $\mathrm{IM}+\mathrm{B}$. It could be concluded that treatment M $(0.45 \mathrm{~kg}$ of milk $\mathrm{DM})$, similar to limit-feeding techniques, encouraged greater calf starter intake in response to receiving less milk DM. Another notable result was that calves fed M and $\mathrm{M}+\mathrm{B}$ had lower FE than calves fed $\mathrm{IM}$ and $\mathrm{IM}+\mathrm{B}$ $(P \leq 0.01)$. This would lead to the conclusion that FE is more closely linked to whole milk consumption than milk DM. In other studies it has been shown that greater volumes of liquid feed offered to calves during the preweaning period can allow calves to reach FE levels of lambs and piglets (Diaz et al., 2001).

In experiment 2, average $\mathrm{BW}, \mathrm{HH}, \mathrm{HW}, \mathrm{WH}$, starter DMI, total DMI, ADG, and FE are shown in Table 3. Again, all Holstein heifer calves automatically entered the trial at birth and were assigned to a treatment where all treatments were represented in each block

Table 2. Average BW, hip height (HH), hip width (HW), withers height (WH), ADG, starter DMI, total DMI, and feed efficiency (FE) calculated for the preweaning period in experiment 1

\begin{tabular}{|c|c|c|c|c|c|c|}
\hline \multirow[b]{2}{*}{ Item } & \multicolumn{4}{|c|}{ Treatment $^{1}$} & \multirow[b]{2}{*}{ SEM } & \multirow[b]{2}{*}{$P$-value } \\
\hline & $\begin{array}{c}\mathrm{M} \\
(\mathrm{n}=20)\end{array}$ & $\begin{array}{c}\mathrm{M}+\mathrm{B} \\
(\mathrm{n}=20)\end{array}$ & $\begin{array}{c}\text { IM } \\
(\mathrm{n}=20)\end{array}$ & $\begin{array}{c}\mathrm{IM}+\mathrm{B} \\
(\mathrm{n}=20)\end{array}$ & & \\
\hline $\mathrm{BW}^{2}(\mathrm{~kg})$ & $51.5^{\mathrm{a}}$ & $54.0^{\mathrm{ab}}$ & $52.9^{\mathrm{ab}}$ & $58.8^{\mathrm{c}}$ & 1.1 & $\leq 0.045$ \\
\hline $\mathrm{HH}^{2}(\mathrm{~cm})$ & 84.1 & 84.2 & 84.1 & 85.1 & 1.3 & $\overline{\leq} 0.6$ \\
\hline $\mathrm{HW}^{2}(\mathrm{~cm})$ & 18.4 & 18.4 & 18.4 & 19.0 & 0.6 & $<0.3$ \\
\hline $\mathrm{WH}^{2}(\mathrm{~cm})$ & 79.8 & 80.0 & 80.0 & 81.0 & 1.2 & $\leq 0.4$ \\
\hline $\mathrm{ADG}(\mathrm{kg})$ & $0.64^{\mathrm{a}}$ & $0.69^{\mathrm{ab}}$ & $0.72^{\mathrm{b}}$ & $0.84^{\mathrm{c}}$ & 0.02 & $\leq 0.01$ \\
\hline Starter DMI $(\mathrm{kg})$ & $31.6^{\mathrm{a}}$ & $24.4^{\mathrm{b}}$ & $23.1^{\mathrm{b}}$ & $19.1^{\mathrm{b}}$ & 2.2 & $\overline{<} 0.01$ \\
\hline Total DMI (kg) & $56.9^{\mathrm{ab}}$ & $62.4^{\mathrm{bc}}$ & $55.6^{\mathrm{a}}$ & $67.9^{\mathrm{c}}$ & 4.9 & $\leq 0.01$ \\
\hline FE (gain:feed) & $0.62^{\mathrm{a}}$ & $0.63^{\mathrm{a}}$ & $0.70^{\mathrm{b}}$ & $0.68^{\mathrm{b}}$ & 0.02 & $\leq 0.01$ \\
\hline
\end{tabular}

$\overline{\mathrm{a}-\mathrm{c}}$ Means within a row with different superscripts differ $(P<0.05)$.

${ }^{1} \mathrm{M}=0.45 \mathrm{~kg}$ of milk DM daily $(\mathrm{d} 1-56) ; \mathrm{M}+\mathrm{B}=0.45 \mathrm{~kg}$ of milk DM $+0.23 \mathrm{~kg}$ of balancer per $0.45 \mathrm{~kg}$ of milk DM daily $(\mathrm{d} 1-56) ; \mathrm{IM}=0.45 \mathrm{~kg}$ of milk DM daily (d 1-14), $0.68 \mathrm{~kg}$ of milk DM daily (d 15-49), $0.34 \mathrm{~kg}$ of milk DM daily (d 50-56); IM+B $=[0.45 \mathrm{~kg}$ of milk DM daily (d 1-14), $0.68 \mathrm{~kg}$ of milk DM daily (d 15-49), $0.34 \mathrm{~kg}$ of milk DM daily (d 50-56)] $+0.23 \mathrm{~kg}$ of balancer per $0.45 \mathrm{~kg}$ of milk DM daily (d 1-56).

${ }^{2}$ The average weight and frame measurements were calculated from birth until weaning. 


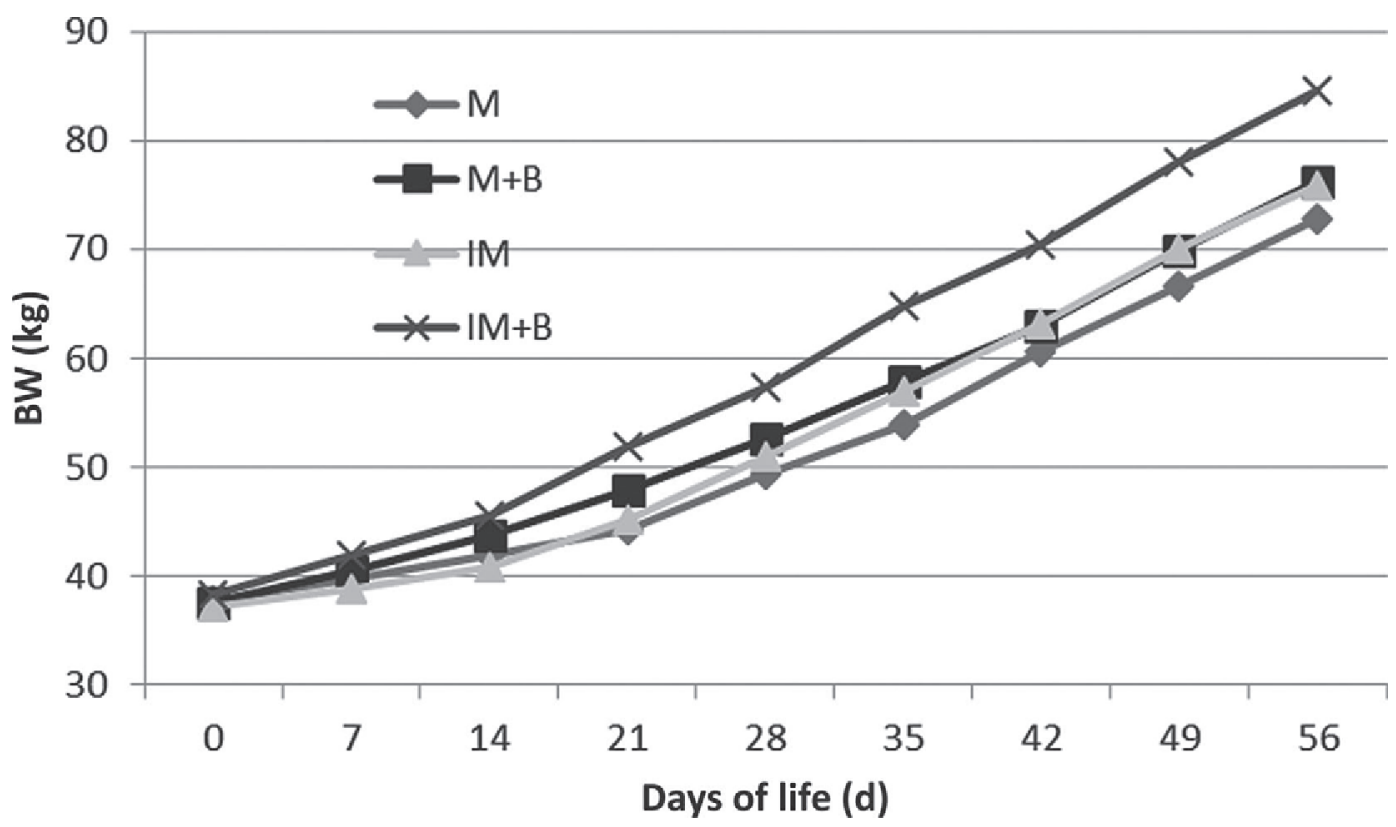

Figure 1. Body weight through the preweaning period by days of life in experiment $1 . \mathrm{M}=0.45 \mathrm{~kg}$ of milk $\mathrm{DM}$ daily $(\mathrm{d} 1-56) ; \mathrm{M}+\mathrm{B}=0.45$ $\mathrm{kg}$ of milk DM $+0.23 \mathrm{~kg}$ of balancer per $0.45 \mathrm{~kg}$ of milk DM daily (d 1-56); IM $=0.45 \mathrm{~kg}$ of milk DM daily (d 1-14), $0.68 \mathrm{~kg}$ of milk DM daily (d 15-49), $0.34 \mathrm{~kg}$ of milk DM daily (d 50-56); IM+B = [0.45 kg of milk DM daily (d 1-14), $0.68 \mathrm{~kg}$ of milk DM daily (d 15-49), 0.34 kg of milk DM daily (d 50-56)] + 0.23 kg of balancer per $0.45 \mathrm{~kg}$ of milk DM daily (d 1-56).

of 3 calves born. Calves fed $\mathrm{IM}+\mathrm{B}$ and $\mathrm{IM}+\mathrm{PB}$ were greater $(P \leq 0.05)$ in average $\mathrm{BW}(56.7$ and $58.2 \mathrm{~kg})$ when compared with calves receiving IM $(53.8 \mathrm{~kg})$, as illustrated in Figure 2. In Figure 2, the weekly BW of calves receiving $\mathrm{IM}+\mathrm{B}$ and $\mathrm{IM}+\mathrm{PB}$ became different $(P \leq 0.05)$ from calves receiving IM by wk 3 and continued through weaning. This resulted in a BW difference at weaning of approximately $5.9 \mathrm{~kg}$ in favor of calves receiving either of the balancer products. Calves receiving a supplemental balancer product also had greater average HW $(P \leq 0.04)$ and $\mathrm{WH}(P \leq 0.04)$. The greater average BW of calves receiving $\mathrm{IM}+\mathrm{B}$ when compared with calves receiving IM was consistent with the results from experiment 1 . It was interesting to note that calves receiving $\mathrm{IM}+\mathrm{B}$ did not differ in the overall average $\mathrm{BW}$ or frame measurements when compared with calves receiving equal amounts of the alternative balancer in treatment IM+PB. According to these results, it would seem that calves were able to use the alternative proteins in the protein-blend milk balancer as well as in the all-milk balancer. Calves receiving IM did consume more calf starter DM $(P \leq 0.01)$; however, when calculating total DMI, calves receiving a supplemental balancer, $\mathrm{IM}+\mathrm{B}$ or $\mathrm{IM}+\mathrm{PB}$, consumed more total DM $(P \leq 0.01)$. Feed efficiency was not different among treatments, which was consistent with the results of $\mathrm{FE}$ in experiment 1 where $\mathrm{FE}$ was linked to milk volume rather than milk DM. Treatments IM, $\mathrm{IM}+\mathrm{B}$, and $\mathrm{IM}+\mathrm{PB}$ included the same volume of whole milk and only differed by supplemental milk DM. As shown in experiment 1, ADG was increased by calves receiving a balancer $(P \leq 0.01)$, with no difference found between balancers $(P>0.2)$. The inclusion of a milk balancer product added to on-farm whole milk may give producers another option to enhance their calf-feeding programs without increasing the whole milk volume provided. To link these initial responses to future milk production, further observations must be collected once the calves have reached the milking herd. In both experiment 1 and 2, no animals were lost and all calves completed the trial.

\section{Health Visual Scoring}

In experiment 1 , evaluation of health scores (Table 4) showed fecal scores were higher $(P \leq 0.05)$ for calves fed $\mathrm{IM}+\mathrm{B}$, with an average of $3.2 \mathrm{~d}$ of scores $\geq 3$, during the 56- $\mathrm{d}$ preweaning period. The other scores for respiratory and attitude showed no differences $(P>0.3$ and $P>0.2$, respectively) between treatments, with an average of less than $0.5 \mathrm{~d}$ scoring $\geq 3$. Even though calves fed $\mathrm{IM}+\mathrm{B}$ had a greater number of days scoring $\geq 3$ for fecal, other studies have shown that increasing milk DM can result in looser stool. In a study conducted by Jenny et al. (1978), the incidences of scouring in liquidfed calves was directly related to DM concentration, with an increase in liquid feed or a decrease in calf starter resulting in an increase of calf diarrhea. This 
Table 3. Average BW, hip height (HH), hip width (HW), withers height (WH), ADG, starter DMI, total DMI, and feed efficiency (FE) calculated for the preweaning period in experiment 2

\begin{tabular}{|c|c|c|c|c|c|c|}
\hline \multirow[b]{2}{*}{ Item } & \multicolumn{4}{|c|}{ Treatment $^{1}$} & \multicolumn{2}{|l|}{$P$-value } \\
\hline & $\begin{array}{c}\mathrm{IM} \\
(\mathrm{n}=24)\end{array}$ & $\begin{array}{c}\mathrm{IM}+\mathrm{B} \\
(\mathrm{n}=24)\end{array}$ & $\begin{array}{l}\mathrm{IM}+\mathrm{PB} \\
(\mathrm{n}=24)\end{array}$ & SEM & $\begin{array}{c}\mathrm{IM} \text { vs. } 1 / 2 \\
(\mathrm{IM}+\mathrm{B}+\mathrm{IM}+\mathrm{PB})^{2}\end{array}$ & $\begin{array}{l}\mathrm{IM}+\mathrm{B} \text { vs. } \\
\mathrm{IM}+\mathrm{PB}^{2}\end{array}$ \\
\hline $\mathrm{BW}^{3}(\mathrm{~kg})$ & $53.8^{\mathrm{a}}$ & $56.7^{\mathrm{b}}$ & $58.19^{\mathrm{b}}$ & 1.0 & $\leq 0.01$ & $\leq 0.3$ \\
\hline $\mathrm{HH}^{3}(\mathrm{~cm})$ & 85.0 & 85.5 & 86.3 & 0.7 & $\leq 0.2$ & $\leq 0.3$ \\
\hline $\mathrm{HW}^{3}(\mathrm{~cm})$ & $18.8^{\mathrm{a}}$ & $19.0^{\mathrm{ab}}$ & $19.4^{\mathrm{b}}$ & 0.2 & $\leq 0.04$ & $\leq 0.1$ \\
\hline $\mathrm{WH}^{3}(\mathrm{~cm})$ & $80.4^{\mathrm{a}}$ & $81.1^{\mathrm{ab}}$ & $82.1^{\mathrm{b}}$ & 0.7 & $\leq 0.04$ & $\leq 0.1$ \\
\hline Average starter DMI/wk (kg) & $2.40^{\mathrm{b}}$ & $1.46^{\mathrm{a}}$ & $1.51^{\mathrm{a}}$ & 0.2 & $\leq 0.01$ & $\leq 0.8$ \\
\hline Average total DMI/wk $(\mathrm{kg})$ & $6.77^{\mathrm{a}}$ & $8.01^{\mathrm{b}}$ & $8.06^{\mathrm{b}}$ & 0.2 & $\leq 0.01$ & $\leq 0.8$ \\
\hline $\mathrm{ADG}(\mathrm{kg})$ & $0.70^{\mathrm{a}}$ & $0.80^{\mathrm{b}}$ & $0.77^{\mathrm{b}}$ & 0.03 & $\overline{<} 0.01$ & $\overline{<} 0.3$ \\
\hline FE (total gain/total DMI) & 0.75 & 0.69 & 0.64 & 0.04 & $\overline{\leq} 0.09$ & $\leq 0.4$ \\
\hline
\end{tabular}

${ }^{1} \mathrm{IM}=0.45 \mathrm{~kg}$ of milk DM daily (d 1-14), $0.68 \mathrm{~kg}$ of milk DM (d 15-49), $0.34 \mathrm{~kg}$ of milk DM (d 50-56); IM+B $=[0.45 \mathrm{~kg}$ of milk DM daily $(\mathrm{d} 1-14), 0.68 \mathrm{~kg}$ of milk DM daily $(\mathrm{d} 15-49), 0.34 \mathrm{~kg}$ of milk DM daily (d 50-56)] $+0.23 \mathrm{~kg}$ of all-milk balancer per $0.45 \mathrm{~kg}$ of milk DM daily (d 1-56); IM+PB $=[0.45 \mathrm{~kg}$ of milk DM daily (d 1-14), $0.68 \mathrm{~kg}$ of milk DM daily (d 15-49), $0.34 \mathrm{~kg}$ of milk DM daily (d 50-56)] + 0.23 $\mathrm{kg}$ of protein-blend balancer per $0.45 \mathrm{~kg}$ of milk DM daily (d $1-56$ ).

${ }^{2}$ Contract between M and the average of MB and MPB; between MB and MPB.

${ }^{3}$ The average weight and frame measurements were calculated from birth until weaning.

could also have been caused by changes in osmolality affecting the absorption of water in the intestines when milk balancer was added to the whole milk and increased the osmolality from 280 to $483 \mathrm{mOsm} / \mathrm{L}$. However, with the other scores for respiratory and attitude showing no significant differences, it was concluded the higher fecal scores were not because of illness. No calves died during this trial and no health concerns greater than diarrhea were reported.

In experiment 2, evaluation of health scores showed fecal scores were higher (Table $5 ; P \leq 0.05$ ) for calves fed either of the supplemental milk balancers compared with IM without balancer. As in experiment 1, the other scores for respiratory and attitude showed no

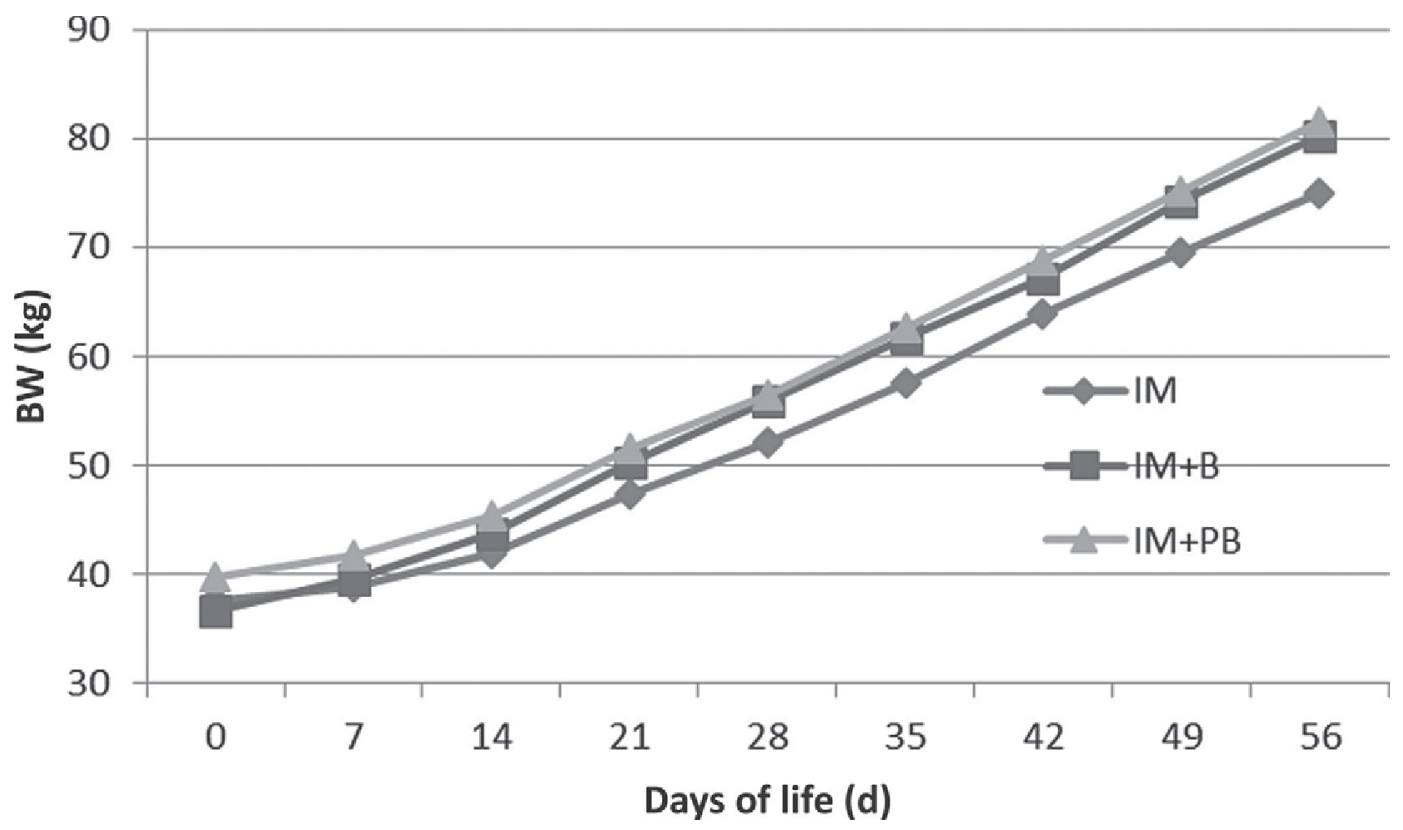

Figure 2. Body weight through the preweaning period by days of life in experiment $2 . \mathrm{IM}=0.45 \mathrm{~kg}$ of milk DM daily (d $1-14), 0.68 \mathrm{~kg}$ of milk DM (d 15-49), $0.34 \mathrm{~kg}$ of milk DM (d 50-56); IM+B = [0.45 kg of milk DM daily (d 1-14), $0.68 \mathrm{~kg}$ of milk DM daily (d 15-49), 0.34 kg of milk DM daily (d 50-56)] + 0.23 kg of all-milk balancer per $0.45 \mathrm{~kg}$ of milk DM daily (d 1-56); IM+PB = $[0.45 \mathrm{~kg}$ of milk DM daily (d $1-14$ ) $0.68 \mathrm{~kg}$ of milk DM daily (d 15-49), $0.34 \mathrm{~kg}$ of milk DM daily (d 50-56)] $+0.23 \mathrm{~kg}$ of protein-blend balancer per $0.45 \mathrm{~kg}$ of milk DM daily (d $1-56)$. Initial birth weights $( \pm \mathrm{SD}): \mathrm{IM}=82.7 \pm 10.2 \mathrm{~kg} ; \mathrm{IM}+\mathrm{B}=81.0 \pm 10.3 \mathrm{~kg} ; \mathrm{IM}+\mathrm{PB}=87.9 \pm 11.5 \mathrm{~kg}$. Final weaning weights $( \pm \mathrm{SD})$ : $\mathrm{IM}=74.9 \pm 7.1 \mathrm{~kg} ; \mathrm{IM}+\mathrm{B}=80.2 \pm 5.0 \mathrm{~kg} ; \mathrm{IM}+\mathrm{PB}=81.4 \pm 8.3 \mathrm{~kg}$. 
Table 4. Health score analyses for fecal, respiratory, and attitude during the preweaning period in experiment 1

\begin{tabular}{lcccccc}
\hline & \multicolumn{9}{c}{ Treatment $^{1}$} & & \\
\cline { 2 - 5 } $\begin{array}{l}\text { Item (average number } \\
\text { of days scoring } \geq 3 \text { ) }\end{array}$ & $\mathrm{M}$ & $\mathrm{M}+\mathrm{B}$ & $\mathrm{IM}$ & $\mathrm{IM}+\mathrm{B}$ & SEM & $P$-value \\
\hline Fecal $^{2}$ & $0.9^{\mathrm{a}}$ & $2.0^{\mathrm{b}}$ & $1.4^{\mathrm{ab}}$ & $3.2^{\mathrm{c}}$ & 0.38 & $\leq 0.01$ \\
Respiratory $^{3}$ & 0 & 0.3 & 0.1 & 0 & 0.1 & $\leq 0.3$ \\
Attitude $^{4}$ & 0 & 0.3 & 0.1 & 0.2 & 0.1 & $\leq 0.2$ \\
\hline
\end{tabular}

${ }^{\mathrm{a}-\mathrm{C}}$ Means within a row with different superscripts differ $(P<0.05)$.

${ }^{1} \mathrm{M}=0.45 \mathrm{~kg}$ of milk DM daily (d 1-56); $\mathrm{M}+\mathrm{B}=0.45 \mathrm{~kg}$ of milk DM $+0.23 \mathrm{~kg}$ of balancer per $0.45 \mathrm{~kg}$ of milk DM daily (d 1-56); IM $=0.45 \mathrm{~kg}$ of milk DM daily (d 1-14); $0.68 \mathrm{~kg}$ of milk DM daily (d 15-49); $0.34 \mathrm{~kg}$ of milk DM daily (d 50-56); IM+B = [0.45 kg of milk DM daily (d 1-14); $0.68 \mathrm{~kg}$ of milk DM daily (d 15-49); $0.34 \mathrm{~kg}$ of milk DM daily (d 50-56)] $+0.23 \mathrm{~kg}$ of balancer per $0.45 \mathrm{~kg}$ of milk DM daily (d 1-56).

${ }^{2} 1=$ normal, $2=$ soft, $3=$ runny, $4=$ watery.

${ }^{3} 1=$ normal, $2=$ runny nose, $3=$ heavy breathing, $4=$ moist cough, $5=$ dry cough.

${ }^{4} 1=$ normal, alert; $2=$ slow to drink or appear mildly depressed; $3=$ mildly depressed, slow to get up and drink; $4=$ severely depressed, does not get up or drink.

differences $(P>1.0$ and $P>0.2)$ between treatments and looser stool was thought to be the result of greater amounts of milk DM fed to the supplemented calves fed $5.7 \mathrm{~L}$ of whole milk (Jenny et al., 1978) and not due to illness. The health scores did not differ between the calves receiving $\mathrm{IM}+\mathrm{B}$ versus $\mathrm{IM}+\mathrm{PB}$. Therefore, substituting the protein-blend milk balancer for the allmilk balancer does not appear to negatively affect calf health.

\section{Verification of Heat Treatment and Passive Immune Transfer}

On-farm batch pasteurization is considered successful at an SPC bacterial count of $<3.5$ or $<5,000 \mathrm{cfu} /$ $\mathrm{mL}$ (Elizondo-Salazar et al., 2010). For effective pasteurization of colostrum, IgG concentrations cannot be reduced to less than $50 \mathrm{~g} / \mathrm{L}$, which is the requirement for high-quality colostrum. The bacterial loads of the whole milk and colostrum were analyzed as SPC, $\log _{10}$ $(\mathrm{cfu} / \mathrm{mL})$. For whole milk, a multiple log reduction was observed (mean $\pm \mathrm{SD}$ ), from $4.9 \pm 0.7$ (range 3.3 to 6.6 ) to $1.7 \pm 0.7$ (range 0 to 3.3 ) in experiment 1 and from $5.0 \pm 1.2$ (range 3 to 7.2 ) to $1.9 \pm 0.6$ (range 1 to 3.3 ) in experiment 2 , between the mean values of pre- and post-heat-treatment milk samples. The colostrum SPC in experiment 1 was reduced (mean \pm $\mathrm{SD})$ from $5.6 \pm 1.2$ to $2.1 \pm 0.6$ with an IgG reduction of $87.5 \pm 28.2$ to $72.7 \pm 26.8 \mathrm{~g} / \mathrm{L}$. In experiment 2 , the colostrum SPC was reduced from $6.1 \pm 0.8$ to $2.3 \pm 0.7$ with an $\operatorname{IgG}$ reduction from $85.8 \pm 31.2$ to $72.9 \pm 29.1 \mathrm{~g} / \mathrm{L}$. The results in both experiments met the standards of on-farm pasteurization for both whole milk and colostrum. Also, in both experiments, SPC $\log _{10}$ results from samples collected after the last calf was fed were variable (experiment 1: $2.0 \pm 0.6 \mathrm{cfu} / \mathrm{mL}$; experiment 2: $2.4 \pm 0.6 \mathrm{cfu} / \mathrm{mL}$ ) due to the amount of time it took to feed the different number of calves at any given period throughout the trial. Other studies have shown significant regrowth of bacteria for samples

Table 5. Health score analyses for fecal, respiratory, and attitude during the preweaning period in experiment 2

\begin{tabular}{|c|c|c|c|c|c|c|}
\hline \multirow[b]{2}{*}{$\begin{array}{l}\text { Item } \\
\text { (average number } \\
\text { of days scoring } \geq 3 \text { ) }\end{array}$} & \multicolumn{3}{|c|}{ Treatment $^{1}$} & \multirow[b]{2}{*}{ SEM } & \multicolumn{2}{|c|}{$P$-value } \\
\hline & IM & $\mathrm{IM}+\mathrm{B}$ & $\mathrm{IM}+\mathrm{PB}$ & & $\begin{array}{c}\mathrm{IM} \text { vs. }{ }^{1 / 2} \\
(\mathrm{IM}+\mathrm{B}+\mathrm{IM}+\mathrm{PB})^{2}\end{array}$ & $\begin{array}{l}\mathrm{IM}+\mathrm{B} \text { vs. } \\
\mathrm{IM}+\mathrm{PB}^{2}\end{array}$ \\
\hline $\mathrm{Fecal}^{3}$ & 1.9 & 4.9 & 5.5 & 1.2 & $\leq 0.02$ & $\leq 0.7$ \\
\hline Respiratory $^{4}$ & 0 & 0 & 0 & 0 & $\overline{\leq} 0.2$ & $\overline{\leq} 1.0$ \\
\hline Attitude $^{5}$ & 0.2 & 0 & 0.1 & 0.1 & $\leq 0.3$ & $\leq 0.2$ \\
\hline
\end{tabular}

${ }^{1} \mathrm{IM}=0.45 \mathrm{~kg}$ of milk DM daily (d 1-14), $0.68 \mathrm{~kg}$ of milk DM daily (d 15-49), $0.34 \mathrm{~kg}$ of milk DM daily (d $50-56) ; \mathrm{IM}+\mathrm{B}=[0.45 \mathrm{~kg}$ of milk DM daily (d 1-14), $0.68 \mathrm{~kg}$ of milk DM daily (d 15-49), $0.34 \mathrm{~kg}$ of milk DM daily $(\mathrm{d} 50-56)]+0.23 \mathrm{~kg}$ of all-milk balancer per $0.45 \mathrm{~kg}$ of milk DM daily (d 1-56); IM $+\mathrm{PB}=[0.45 \mathrm{~kg}$ of milk DM daily (d 1-14), $0.68 \mathrm{~kg}$ of milk DM daily (d 15-49), $0.34 \mathrm{~kg}$ of milk DM daily (d 50-56)] $+0.23 \mathrm{~kg}$ of protein-blend balancer per $0.45 \mathrm{~kg}$ of milk DM daily (d 1-56).

${ }^{2}$ Contrast between IM and the average of $\mathrm{IM}+\mathrm{B}$ and $\mathrm{IM}+\mathrm{PB}$; between $\mathrm{IM}+\mathrm{B}$ and $\mathrm{IM}+\mathrm{PB}$.

${ }^{3} 1=$ normal, $2=$ soft, $3=$ runny, $4=$ watery.

${ }^{4} 1=$ normal, $2=$ runny nose, $3=$ heavy breathing, $4=$ moist cough, $5=$ dry cough.

${ }^{5} 1=$ normal, alert; $2=$ slow to drink or appear mildly depressed; $3=$ mildly depressed, slow to get up and drink; $4=$ severely depressed, does not get up or drink. 
taken after the last calf was fed, because pasteurization and heat-treatment techniques can only be effective when coupled with good management techniques (Elizondo-Salazar et al., 2010). Minimizing the time the pasteurized milk stands at feeding temperatures of $40^{\circ} \mathrm{C}$ will limit the opportunity for bacterial regrowth.

Providing high-quality colostrum is a fundamental part of calf management that has been well documented based on the necessity of passive immune transfer from dam to calf through IgG proteins (Furman-Fratczak et al., 2011). When using the heat-treated colostrum, nearly all calves (98\% in experiment 1; $95 \%$ in experiment 2) received successful passive immune transfer as defined by a serum IgG level of $\geq 10 \mathrm{mg} / \mathrm{mL}$ or serum protein level of $\geq 5 \mathrm{~g} / \mathrm{dL}$. The mean values of serum protein for experiment 1 and 2 were $6.0 \pm 0.6$ (ranging 4.8 to 8.6 ) and $6.1 \pm 0.7 \mathrm{~g} / \mathrm{dL}$ (ranging 4.4 to 7.9 ), respectively. Similarly, serum IgG means for experiment 1 and 2 were $25.3 \pm 9.1$ (ranging 2.5 to 63.0 ) and 26.0 $\pm 11.8 \mathrm{~g} / \mathrm{L}$ (ranging 6.2 to 59.4), respectively. These results indicate that the heat-treatment technique developed by Godden (2008) heating colostrum at $60^{\circ} \mathrm{C}$ for $60 \mathrm{~min}$ did not prevent the calves from receiving successful passive immune transfer.

\section{CONCLUSIONS}

In experiment 1 , the findings demonstrate an option for producers to increase $\mathrm{ADG}, \mathrm{BW}$, and $\mathrm{FE}$ in their preweaned calves through the use of whole milk and milk balancer products as an alternative to increasing the volume of whole milk provided. In experiment 2, the findings document that increased $\mathrm{ADG}, \mathrm{BW}$, and $\mathrm{FE}$ in preweaned calves can be achieved through the use of whole milk and milk balancer products with alternative protein sources that could decrease initial investment costs. The effectiveness of heat treating both colostrum and whole milk at a lower temperature is consistent with other studies as an option to decrease bacterial contamination and risk of disease while maintaining effective transfer of passive immunity. However, the importance of investing in the preweaning period for heifer calves must be beneficial for future performance as cows. Longer-term observations are needed to determine the effects of various approaches to neonatal nutrition on subsequent milk yield and composition.

\section{ACKNOWLEDGMENTS}

We acknowledge Land O'Lakes Inc. (St. Paul, MN) and Dairy Tech Inc. (Windsor, CO) for their financial support and for providing essential equipment. We also acknowledge the staff at the North Carolina Department of Agriculture Piedmont Research Station (Salis- bury, NC) and the North Carolina State University Dairy Farm Educational Unit (Raleigh, NC) for their help and support in completing this project.

\section{REFERENCES}

Brown, E. G., M. J. VandeHaar, K. M. Daniels, J. S. Liesman, L. T. Chapin, J. W. Forrest, R. M. Akers, R. E. Pearson, and M. S. W. Nielson. 2005. Effect of increasing energy and protein intake on mammary development in heifer calves. J. Dairy Sci. 88:595-603.

Cho, H. C., and T. T. Kramer. 1970. Radial immunodiffusion of chicken serum proteins I. Standardization of optimal test procedures. Can. J. Comp. Med. 34:341-346.

Daniels, K. M., J. K. E. Webb, L. McGilliard, M. J. Meyer, M. E. V. Amburgh, and R. M. Akers. 2006. Effects of body weight and nutrition on mammary protein expression. J. Dairy Sci. 89:42764288.

Davis Rincker, L. E., M. S. W. Nielson, L. T. Chapin, J. S. Liesman, and M. J. VanderHaar. 2008. Effects of feeding prepubertal heifers a high-energy diet for three, six, or twelve weeks on feed intake, body growth, and fat deposition. J. Dairy Sci. 91:1913-1925.

Diaz, M. C., M. E. V. Amburgh, J. M. Smith, J. M. Kelsey, and E. L. Hutten. 2001. Composition of growth of Holstein calves fed milk replacer from birth to 105-kilogram body weight. J. Dairy Sci. $84: 830-842$.

Drackley, J. K. 2008. Calf nutrition from birth to breeding. Vet. Clin. North Am. Food Anim. Pract. 24:55-86.

Elizondo-Salazar, J. A., C. M. Jones, and A. J. Heinrichs. 2010. Evaluation of calf milk pasteurization systems on 6 Pennsylvania dairy farms. J. Dairy Sci. 93:5509-5513.

Furman-Fratczak, K., A. Rzasa, and T. Stefaniak. 2011. The influence of colostral immunoglobulin concentration in heifer calves' serum on their health and growth. J. Dairy Sci. 94:5536-5543.

Godden, S. 2008. Colostrum management for dairy calves. Vet. Clin. North Am. Food Anim. Pract. 24:19-39.

Godden, S., S. McMartin, J. Feirtag, J. Stabel, R. Bey, S. Goval, L. Metzger, J. Fetrow, S. Wells, and H. Chester-Jones. 2006. Heattreatment of bovine colostrum. II: Effects of heating duration on pathogen viability and immunoglobulin G. J. Dairy Sci. 89:34763483.

Jenny, B. F., S. E. Mills, W. E. Johnston, and G. D. O'Dell. 1978. Effect of fluid intake and dry matter concentration on scours and water intake in calves fed once daily. J. Dairy Sci. 61:765-770.

Kehoe, S. I., C. D. Dechow, and A. J. Heinrichs. 2007. Effects of weaning age and milk feeding frequency on dairy calf growth, health and rumen parameters. Livest. Sci. 110:267-272.

Meyer, M. J., A. V. Capuco, D. A. Ross, L. M. Lintault, and M. E. V. Amburgh. 2006. Developmental and nutritional regulation of the prepubertal heifer mammary gland: I. Parenchyma and fat pad mass and composition. J. Dairy Sci. 89:4289-4297.

Montagne, L., R. Toullec, T. Savidge, and J. Lalles. 1999. Morphology and enzyme activities of the small intestine are modulated by dietary protein source in the preruminant calf. Reprod. Nutr. Dev. 39:455-466.

Morrill, J. L., J. M. Morrill, and A. M. Feyerherm. 1995. Plasma proteins and a probiotic as ingredients in milk replacer. J. Dairy Sci. 78:902-907.

Nero, L. A., V. Beloti, M. De Aguiar, F. Barros, M. B. T. Ortolani, R. Tamanini, and B. D. G. De Melo Franco. 2006. Comparison of petrifilm aerobic count plates and de Man-Rogosa-Sharpe agar for enumeration of lactic acid bacteria. J. Rapid Methods Autom. Microbiol. 14:249-257.

Quigley, J. D., and T. M. Wolfe. 2003. Effects of spray-dried animal plasma in calf milk replacer on health and growth of dairy calves. J. Dairy Sci. 86:586-592.

Soberon, F., E. Raffrenato, R. W. Everett, and M. E. V. Amburgh. 2012. Preweaning milk replacer intake and effects on long-term productivity of dairy calves. J. Dairy Sci. 95:783-793. 